\title{
MUTUAL CONVERSION?
}

\author{
THE METHODIST CHURCH AND THE YOLDU, WITH PARTICULAR \\ REFERENCE TO YIRRKALA
}

\section{HOWARD MORPHY}

\section{INTRODUCTION: BEGINNINGS AND BIASES}

A history of the Methodist Overseas Mission in Arnhem Land has yet to be written. The resources for such a task are immensely rich, including archival sources and the writings of the missionaries themselves. While not possessing its own historian, as the Anglican missions do in the person of Reverend Keith Cole, ${ }^{l}$ the Methodist Church produced a number of educated and passionate superintendents who wrote detailed accounts of their times and experiences. Yirrkala alone had at least three, in Wilbur Chaseling, ${ }^{2}$ Harold Thornell ${ }^{3}$ and Edgar Wells ${ }^{4}$. This paper is very much a preliminary excursion into the arena; it is not a history or a case study but rather a proposition, supported by evidence from different sources and periods; an argument that comes, perhaps a little too intuitively, out of my own sense of the history of north east Arnhem Land. It is an argument that develops in a complementay manner to other, received, viewpoints that are in themselves undoubtedly oversimplified and open to challenge - the sense that the neighbouring Anglican and Catholic missions were less positive in their view of
Aboriginal religion and culture, and were more likely than the Methodist Church to introduce potentially destructive institutions such as the dormitory system and the banning of traditional ceremonial practices (see Mickey Dewar, this issue). Yet in most respects the Anglican and Catholic Churches have been equally strong in their advocacy of Aboriginal rights.

The title of my paper, 'mutual conversion', exaggerates the case but perhaps only a little. There were some intolerant Methodists, who viewed Aboriginal practices simply as heathen forms. There were missionary linguists who refused to translate Indigenous songs or document bark paintings - the sanctity of written Yolnu had to be preserved for the production of biblical texts. Religious tolerance applies more to some times and some individuals than others, but as encounters between Aborigines and missionaries go, that between the Yolyu and the Methodist Overseas Mission was a relatively fortunate one. If bigotry can be defined by its resistance to argument, by its failure to see the other point of view, by its antipathy to choice, then the Methodist Church in Arnhem Land provides a poor example. Indeed the case is not so much 
an illustration of bigotry as of its opposite, which must involve tolerance and respect but may also include doubt and uncertainty.

The paper is very much a preliminary exercise; it is also partial, perhaps in two senses. It is partial in that I have not fully explored the documentary record. I depend too much on published materials, supported by recorded interviews with the protagonists. I need to do much more work in the archives. My account may also be partial in the second sense that I am biased by my relationship with the missionaries I have met and by the historical context of my own research. I first visited north east Arnhem Land in 1973 in the company of the Reverend Edgar Wells and his wife Anne. Edgar had applied to the Australian Institute of Aboriginal Studies for a grant to redocument bark paintings collected by the founding missionary, the Reverend Wilbur Chaseling. The Institute gave him a grant on condition that I, a newly arrived researcher from England, was allowed to accompany him. We spent a week at Yirrkala and a week at Milingimbi. Yirrkala had been established in 1935 and Milingimbi, the first mission in the Yolyu region, in 1926. Edgar Wells had spent 10 years as superintendent at Milingimbi and was stationed at Yirrkala during 1962 and 1963. Wells had worked closely with the people of Yirrkala to fight the granting of a lease to mine bauxite over their lands and played a significant role in the battle for land rights. I admired him for what he had done and we got on very well. However his return visit was also charged with tension. Some people had found Edgar a difficult man. At the time of the Yirrkala crisis he maintained strict control over his European staff, censoring their correspondence and forbidding them to speak with government officials. He believed that the government and the mission were involved in a conspiracy to grant the mining lease and did not trust anybody. ${ }^{5}$ He was probably right about the conspiracy, but the way he handled the situation alienated him from some of his own staff. As a consequence he received a cool reception from the mission staff at Yirrkala, in direct contrast to his reception at Milingimbi and to the warmth with which he was received by Yolnu at both places.

The other source of bias is in Yolyu memories of the past. I have no direct data on what Yolyu thought of the missionaries before my fieldwork began in the 1970s. My work in the Roper Valley suggests that people often create a golden age in contrast to the present which over-emphasises the harmonious state of relationships in the past. ${ }^{6}$ In the Roper Valley the period of the 1930s to the 1950s was portrayed as a Golden Age sandwiched between the killing times of the African and Asian Cold Storage Company and the confrontational relationship that developed in the 1960s, after equal award wages had been granted to Aboriginal workers on cattle stations. In the Arnhem Land case there was different bread in the sandwich. The time prior to the establishment of the mission was also a time of violence, involving both confrontation with outsiders and inter-clan warfare, and the 1970s brought the mining town and almost catastrophic disruption to Yolnu life. It is quite likely that this biased oral accounts in the missionaries' favour. 


\section{THE DIALOGUE COMMENCES}

In this paper I aim to outline the history of interactions between Yolyu and missionaries, in particular highlighting discourse over religion and cultural values. My primary focus is on Yirrkala, the last mission to be established in eastern Arnhem Land. Mission stations had been gradually established along the Arnhem Land coast during the first half of the last century. They spread out from the areas of earliest European settlement towards those areas beyond the frontier. The Methodist Overseas Mission moved from the west to east along the north coast, from Goulburn Island to Milingimbi and Elcho Island, and the Church of England moved north from cattle country in the Roper Valley to Groote Island. A mission station or two in the region of Yirrkala and Caledon Bay were the next ones to be planned. The planning process was given added impetus by what has come to be known as the Caledon Bay killings. ${ }^{7}$ In the 1930s people from Caledon Bay and Blue Mud Bay killed a number of outsiders on their land, including the crew of a Japanese pearling lugger at Caledon Bay in 1933. A police party was sent out to investigate, and this led to the killing of one of the party, Constable McColl, on Woodah Island in the north of Blue Mud Bay. Originally there was pressure from the police to send in an expeditionary force to take control of the area and 'teach the blacks a lesson'. ${ }^{8}$ The Anglican Church led by the Reverend Warren of Groote Eylandt, together with the Methodists strongly resisted the idea and convinced the federal government to follow a very different course of action. ${ }^{9}$ The anthropologist Donald Thomson was sent to Arnhem Land to uncover the concerns of the Yolyu people and the Methodist Overseas Mission was given the go-ahead to establish a station at Yirrkala, overruling the claims of the Church Missionary Society.

It was decided to locate the settlement at Yirrkala, because it had an excellent permanent water supply and was in a sheltered location with apparent potential for developing gardens. The foundation missionary was Wilbur Chaseling, who arrived with his wife in 1935. The context of the founding of the mission was significant: Yolyu had found the previous few years very stressful because of the increase in violent encounters with outsiders, the arrests of clan members and the threat posed by the police. ${ }^{10}$ At the same time there had been an increase in clan warfare, probably exacerbated by the encroachment of Europeans in the south and west. Yolyu today recall that Wonggu and other clan leaders made a conscious decision to make peace with outsiders rather than continue hostilities, and the missionaries presented themselves as peacemakers. Chaseling was surprised by the speed with which Yolnu moved to settle in the mission. When I interviewed Chaseling in 1973 about the early years of Yirrkala at one point he asked rhetorically: ${ }^{11}$

Why did they come? For curiosity, medical benefits, and because we were a new type of people - not police, Macassans, pearlers, Japanese - a new type of person without guns, working for their benefit, curing little children suffering from yaws - within a few weeks the scales falling off.

Yolnu moved to the mission station of their own free will and with no suggestion 
that they had been conquered or had ceded any rights to outsiders. Equally important was the fact that the government had transferred effective authority to the missionaries, who became a de facto instrument of government, administering the region and introducing a system of local law. Their presence solved a major problem for the government; the area was pacified with no loss of life and administered with little cost to the budget. Yet although they carried out the functions of government the missionaries presented themselves as being independent of it. For most of the subsequent life of the mission the missionaries saw themselves operating as representatives of the Yolyu people rather than of the central government. Indeed in Yolyu discourse missionaries were opposed to government men and, interestingly, when the government sent Bill Grey, a patrol officer, to be their first permanent representative to the region in 1963, the missionaries insisted that he camp in a caravan outside the settlement. Grey was sent as a government representative in response to the protests by Yolyu and missionaries over the bauxite mining proposals. 12

The trajectory of the mission at Yirrkala was set by the earlier practice established at Goulburn Island and in particular at Milingimbi under the auspices of Theodore Webb. Webb showed a deep interest in Aboriginal culture. He had a number of motivations for this: he believed that effective missionisation could only occur with a background of cultural knowledge; he realised that craft production provided a potential source of external income; and he realised the need to inform the Mission's supporters in the southern States about the Yolyu way of life, both to gain support and rid them of misconceptions. ${ }^{13}$ All of these motivations however presupposed a respect for, or at least an understanding of the autonomous nature of, Aboriginal culture. By the time Chaseling was preparing to leave for his vocation, the Methodist Mission was encouraging their senior staff to learn some anthropology under Professor A. P. Elkin at Sydney University.

A number of the missionaries have written books on their life among the Yolyu: Webb, 14 Chaseling, 15 Thornell 16 and Anne Wells. ${ }^{17}$ The books combine lay ethnographic accounts of the Yolyu way of life and semi-autobiographical accounts of mission life, but they also contain reflective passages that outline the main aims and aspirations of the missionaries. Two themes come across strongly and consistently, a Protestant work ethic and religious tolerance. Mickey Dewar 18 has drawn attention to the former theme and I will only briefly allude to it here. There was a strong belief in the dignity of labour, linked to a quasi-evolutionary theory that it was necessary to lead Yolyu from the state of hunting and gathering through agriculture to a broader participation in the Australian economy. This economic transformation was not seen as being incompatible with respect for Aboriginal culture, and indeed the intention was to build on the Indigenous skills base. These aims were explicit in Chaseling's and his successor Thornell's policies. In my interview with him Chaseling stated:

I started them painting craft within a week or so of arriving. I established the principle that I would give them nothing free - nothing except medicine. If they were to 
get things they had to work. I sent things only to museums and charged them the price I paid plus freight - I sent tons of stuff down. I realised that we had to start some kind of industry and craft seemed the most obvious one, even if I had to burn some of the things produced at first I had to do it. 19

Tolerance and understanding of Aboriginal culture combined with an agenda of economic development were developed as policies at the Yirrkala Synod of 1938. According to Thornell 'It was realised that sooner or later contact with our culture and economic way of life was inevitable'. ${ }^{20}$ The policy was to prepare them without harming their culture: 'It was important to respect Aboriginal culture instead of destroying it, important to better understand the culture, and to learn and use the Aboriginal language. One other vital point was that there were to be no hand outs. Nothing would be given unless it was earned.' 21

Chaseling's and Thornell's attitudes to Yolyu religious practice were generally positive. In his book Yulengor published in 1957 with a preface by A. P. Elkin, Chaseling wrote:

(It) seemed only reasonable at Yirrkala to preserve Yulengor [Yolngu] culture. To encourage the revival of old ceremonies, and to stimulate in the people an appreciation of their own social organization which often suffered from alien contact. It is unjust for any alien to come amongst primitive people for the purpose of upsetting their mode of life and converting them to thinking as he does.
In my interview with Chaseling he said:

I found close parallels between the Christian religion and Yolngu religion. In fact when I first arrived I found that there was more for me to learn. I was able to gain insights into the significance of religion in its natural context and on the basis of their own beliefs I was able to begin to introduce the Christian gospel. To lead them one step at a time to the acceptance of the teachings of our Lord. I found it difficult at first - but they went away, talked among themselves and applied it. ${ }^{22}$

Chaseling's words are echoed in those of another missionary, the Fijian Fuata Taito, based at Goulburn Island in the 1940s: 'Some of these customs could be used as a step towards Christianity, instead of our telling them it is foolish to follow customs'. 23 In much of the writings of Methodist missionaries of the time there is an often unspoken tension between using Indigenous religion as part of the process of conversion and recognising value in Aboriginal religious practice.

\section{THE DISCOURSE DEVELOPS}

Chaseling gave me an example of the religious discourse he conducted with Yolyu elders. He drew an analogy between one of the sets of ancestral beings of the Dhuwa moiety - the Djan'kawu - and Christian cosmology:

You have your Djan'kawu and we have ours - ours was the God of the Old Testament - yours made mistakes and so did ours. Our God 
sent Christ to show us what those mistakes were and the Wangarr [Ancestral Beings] sent you the balanda and the balanda [white people] can tell you the whole truth. For example our God of the Old Testament talked of an eye for an eye and a tooth for a tooth just like your Djan'kawu encouraged you to take revenge - kill one of twins, although there was plenty of food for everyone. Wangarr sent Jesus to teach you and your children that this is wrong - find a greater sense of independence, as I said you know the facts - go and work them out. 24

His arguments reflect a liberal Protestant theology that is in its own terms opposed to bigotry, allowing a degree of individual freedom to make decisions on the basis of knowledge and experience.

This interest went beyond what was necessary to convert Yolyu to Christianity, and had from early on hints of syncretism or perhaps even religious pluralism that have subsequently come to characterise Yolyu religious practice. In Yulengor Chaseling writes appreciatively about Aboriginal religion, arguing for continuity to be maintained. He argued that in order to win people's confidence there must be an appreciation of their religion as religion permeates all aspects of Aboriginal life, 'and determines even his methods of food gathering and cooking ... the simplest activities are linked to his highest beliefs and noblest aspirations.' The customs are linked together in a systematic way and cannot be tampered with without endangering the whole structure of life. 'An ef- fective approach to the nomad can be made only on the basis of religion'. ${ }^{25}$

While this certainly reflects Chaseling's approach at the time he also acknowledged that the passage of time influenced his attitudes. Writing to Ed Ruhe in 1965 about art production during his time at Yirrkala he said: 'I find this whole subject the more fascinating with the passing of years, much in the same way as I become more interested in the developing philosophy and theology of these people whom I knew so well in the Yirrkala area.' 26

The syncretic dimension, but also perhaps the retrospective romanticism, comes out clearly in the following passage from Thornell reflecting on a cultural performance he witnessed when he returned to Yirrkala in 1979, 30 years after he had left:

We were at Yirrkala on 6 July when the town celebrated National Aborigines day, and Aborigines of all ages, plus some white onlookers, gathered together in a clearing near the primary school for authentic native dancing to the beat of clap-sticks and the sound of the drone pipe. I was strongly reminded of the nightly singing around the campfire long ago. There isn't so much ceremonial dancing and singing now, especially among young people. It would be a great pity if it were allowed to die out, for it is a unique form of artistic expression. Among the young people of Yirrkala now there is a different kind of singing. Most nights they gather around a bonfire - to simulate the atmosphere of the tribal campfire but instead of ceremonial singing 
and dancing the young people sing hymns learnt on Church gatherings. There is an air of spontaneity about it ... a young man may read a passage from the Bible ... another may give an impromptu sermon. Yet there is nothing over emotional about it. After all spiritual things have been vital to the Aborigines from time beyond thought. The only difference is that these young people have chosen Christianity. I see no reason why Christianity and the traditional cultural songs and dances cannot exist together. 27

And indeed had Thornell's visit to the region been more prolonged he would have again heard 'the singing around the campfire' and realised that many Yolyu shared his view on the co-existence of Christianity with Yolyu religion. Daymbalipu Mununggurr, talking to Ian Dunlop in 1974 expressed the relationship in the following words: 'This time is a little bit different because there are two ways we see. One is the Christian way, one is our law, the Aboriginal law. These laws do not hate each other. We like to make a good law, leading to peaceful ways'. ${ }^{28}$

This dialogue between Yolyu religion and Christianity set in motion in the first years of missionisation has had a continuing impact over time. We do not have direct evidence of how Yolyu responded to Chaseling and the role that they took in carrying the syncretic dialogue forward. We do not know what challenges there might have been to the positioning of Djan'kawu as an Old Testament figure. However there are hints in Chaseling's writings:
Several old men were talking together and invited me to join them. One of them said: 'We like those stories of Jesus that you tell us: He is white man's Junkgowa [Djan'kawu]. Our Junkgowa came from the Wangarr and we can see now that, in the same way, Jesus is the Whiteman's Junkgowa. ${ }^{29}$

However, the theological discourse that we can imagine occurring from the beginning has remained a strong component of Yolyu culture. In 1982 Ian Dunlop filmed a fellowship meeting of young Yolyu sitting talking, playing the guitar and drinking kava. Wuyuwa Mununggurr led the discussion with her husband Djoki Yunupingu.

She began by posing a question: 'What law does this sacred dilly bag hold, compared with the law of the Bible? What do they both represent, what do you see in these two?'

Djoki continued: 'They both have equal status, both are sacred they are both telling the same. The Bible tells us sacred stories and the same with the dilly bags, they tell us about the sacred law.'

Wuyuwa: 'True.'

Chorus of young people: 'Yes!'

Wuyuwa: 'When people dance or [the dilly bag] is brought out for other reasons, we only see the outside of the dilly bag, but it carries an "inside" story, it is just the same. Our law that it carries and the stories. The sacred dilly 
bag carries them just like the Bible.' 30

In this dialogue people are referring to the elaborately crafted and featherdecorated bags that are used in ceremonies and that often contain objects associated with the sacred life of particular clans. ${ }^{31}$ These baskets are themselves associated with stories of the clan's ancestral heritage and are linked to particular people and places. 'Inside' refers both to the interior of the dilly bag and the pages inside the Bible and also to the inside level of spiritual knowledge which echoes Christian conceptions of inner truth. The discussion hints at the rich metaphorical nature of Yolyu religious practice and the multiple possibilities of finding points of connection with Christianity.

The discourse between Yolyu and Christian missionaries has produced a significant number of syncretic events, some initiated by Yolyu leaders and theologians others encouraged by the missionaries themselves. The two best known manifestations of this are probably the Elcho Island Memorial of 1957 and the Yirrkala Church Panels of 1962. Both events involved the installation of major icons of Yolyu religion in a Christian context. The Elcho Island Memorial was erected outside the church at Galiwinku (Elcho Island). It comprised a series of wooden sculptures based on the form of sacred objects belonging to the northern Yolyu clans. The Yirrkala Church Panels were two masonite panels painted with designs from each of the clans represented at Yirrkala. These were placed on either side of the altar of the new Yirrkala Church. The events were very different ones, but they had in common the assertion that Yolyu had objects of religious value that were equivalent to the icons of
Christianity and that these icons should have a role in the discourse between cultures.

The events that gave rise to the Elcho Island Memorial were led entirely by Yolnu and had a complex set of motivations. 32 In addition to asserting the equivalent value of Yolyu religious icons and outlining Yolyu political objectives, the Memorial also implied or enacted a change in Yolnu religious practice - a bringing out into the open of forms that had previously been restricted, and the sharing of those forms on a wider basis. It was part of the dialogue with Christianity that involved a shift from 'inside' to 'outside' - a modification of elements of Yolyu religious practice to accommodate changing circumstances. ${ }^{33}$ The Memorial also had a political dimension; it asserted Yolyu autonomy and rights, while acknowledging that those rights had to be incorporated in a wider political structure. While most Yirrkala clans refused to participate in the Elcho Island Memorial, partly through concern over the opening out of previously restricted objects, it can nonetheless be seen as contributing to the possibility of the Yirrkala Church Panels. The Yirrkala Panels also required the exhibition of religious art in a public space even if that space was the consecrated space for another 'local' religion. ${ }^{34}$

The Yirrkala Church Panels were explicitly syncretic and in continuity with the dialogue set in place by Chaseling. According to Edgar Wells, Narritjin Maymuru proposed the idea of the church panels to him, but Wells' own respect for Aboriginal religion may also have been a factor. He believed that all religions had the capacity to produce mystical insights that could increase understanding. This comes out 
most clearly in a letter he wrote to his long-term correspondent Ed Ruhe in 1983:

You must know that there are moments of illumination when the mind expands under the force of new horizons ... it is the force of such encounters within the spiritual realm ... that has kept me within the [Christian] group. It is because I was able to minister to the Aborigines in this special way of causing a stretch ... of thought processes ... that men such as Djawa and Narritjin could expose little cracks of their own mountain ranges ... that made areas of understanding possible. They did not of course have to become Christians to receive this illumination - and this is where some of my companions in missionary activity part company with me. ${ }^{35}$

The Church Panels were also a religious expression of a political aim in which both the Yolyu and the missionaries concerned were united - the recognition of Yolyu rights in land. The paintings were a response to the mineral explorations and to concerns over the possible granting of a mining lease over the bauxite reserves on the Gove Peninsula. They led directly to the Yirrkala Bark Petition that was sent to the Commonwealth parliament in the following year. Kim Beazley senior saw the panels in the Church, and suggested that this would be an appropriate way to petition parliament using the symbolic medium of Yolyu religion and law. The Gove Land Rights case can be seen as a logical outcome of the dialogue that occurred. ${ }^{36}$

\section{MUTUAL DOUBTS}

It is likely that from the very beginning Yolyu and missionaries had moments of doubt, scepticism, and resistance to the dialogue that was developing. Missionaries and Yolyu clearly differed among themselves and some missionaries were downright hostile to Yolyu religious practice. Chaseling expressed his own uncertainty: he is unsure about this equivalence, in effect, between Wangarr and God but concludes that 'Wangarr is scarcely less vague in the nomads mind than the "Eternal" of the early pages of the bible.' But he lets it go since 'It enables Jesus to be accepted without doing damage to Yolyu culture'. 37

There were, as Wells hints, missionaries who took a very different view from his own and who saw 'heathen' customs in Aboriginal religious practice. Some of the missionaries who followed Wells at Milingimbi were less tolerant of Aboriginal religious practice than he was.

One of the main contexts of potential conflict is in mortuary rituals, where both Yolyu religious practice and Christianity come together in the disposal of the dead. Yolyu mortuary rituals extended over a lengthy period and involved both a secondary stage, when the bones of the deceased were collected and carried around in a bark coffin for several months or even years, and a tertiary stage when the bones were placed in a hollow log coffin. Yolyu mortuary practices offended the sensibilities of some missionaries, contradicted their pollution beliefs and, because of their extended nature, threatened to interrupt the economic life of the settlement. Over time Yolyu mortuary rituals have evolved to incorporate both religions, with different 
spaces or stages in the proceedings being allocated to each. Christian prayer and the viewing of the body are interspersed with Yolyu ritual performance until the climax of the ceremony. The body is brought to the ceremonial ground and placed in the grave through Yolyu performance, before being buried in a Christian ritual. Sometimes the divisions are less clear cut and some elements combine Christianity and Yolyu practice in the same event. Not surprisingly it is in these events, in which the two beliefs systems directly confront each other, that conflict sometimes occurs. Certainly they generate mixed emotions.

When I visited Milingimbi with Edgar Wells, the community leader Djawa led us away one evening to talk to an old man, Dawarangalili. A central element of Yolyu mortuary rituals was the painting of clan designs on the dead person's chest. Wells and the missionaries who had preceded him were perfectly happy to allow this practice. However one of the ministers who followed him had insisted that if people were to have a Christian burial then they could not be buried with a painted chest. Dawarangalili asked Wells to intervene and indeed poignantly stated that he had delayed dying because of his fear of being buried without the painting on his chest.

What Wells himself referred to as fundamentalism increased after the 1970s. At Yirrkala in 1975 the local minister almost literally threw the Church Panels into the street, wanting to rid the church of heathen idols.

The syncretic discourse between Yolyu and Methodists has involved changes in Yolyu religious practice that are at least as great as the concessions made by the missionaries. In north east Arnhem Land there has been a gradual process of opening out of Indigenous religious practice, a reduction in the role of secrecy, without any sense that the icons of the religion - the paintings, songs, dances and sacred objects - have lost their power. The panels placed on either side of the altar in 1962 contained paintings that a few years previously had been used largely in restricted contexts, and appeared in public contexts in slightly modified form. Yolyu and missionaries alike express doubts and anxiety in some of the same contexts - where Christian and Yolyu religious practices come into potential conflict. There is anxiety over the opening out of Yolyu religious practice, and there are questions of compatibility in shared contexts. The adjustments that have been made to the European colonial presence at times seem to have come at too great a cost. A recent case can be used to exemplify the kinds of issues that arise in the contemporary context, though it must be stressed that Yolyu attitudes to Christianity are very diverse, reflecting a number of different religious orientations within eastern Arnhem Land that are linked to different movements in the wider Church. 38

Recently a Yolyu person developed a serious eye infection and put it down to exposure to sacred religious objects at a burial ceremony. The person said that the funeral combined Christian and Yolnu ritual and that they felt uncomfortable about the Yolyu ritual inside the church. There was particular concern that a wapitja, a ceremonial digging stick, was taken into the church - it made the person feel sick inside. The person felt that Yolyu ritual was for outside and before the final internment. The person concerned argued that God had given the Yolyu ancestors a 
caretaker role but that they were under the more general spiritual authority of God. The person took a middle ground between those who see Yolyu religion as incompatible with Christianity and those who see it as autonomous. Yolyu religion is seen in this case as local representation of God's power. It was not that the digging stick was a restricted sacred object. It was more a matter of combining Yolyu religious practice and Christianity in the same context, under the same roof. The person would have been quite happy if the events had followed one another sequentially separated in time and space: the digging stick in the camp, the prayers in the church. The fact that those boundaries appeared to have been crossed was believed to have made the person spiritually vulnerable, causing the illness.

\section{CONCLUSION}

The dialogue between practitioners of Yolyu and Christian religion is an ongoing one. It has produced a society in which religion is as alive and central to the community as anywhere else in Australia, and more central than in most places. It is interesting that the dialogue has become, over time, less one of race than of religious belief. Yolyu have become Christians yet simultaneously maintained much of their own religious practice. Indeed Yolyu have themselves taken on the role of missionaries both as Christian ministers yet also as advocates for Yolyu religion. Yolyu religion has become part of an outgoing culture of persuasion that combines political, religious and spiritual objectives. Yolyu continue to insert their religious values through cultural performances into EuroAustralian contexts - through participa- tion in the Olympic opening ceremony, through the Bangara Dance Company and The National Aboriginal Islander Skills Development Association (NAISDA) Inc. and art exhibitions such as the Saltwater Paintings. ${ }^{39}$ Yet Yolyu are equally concerned internally with accommodating Christian dogma and belief within their local framework of religious action. The lack of dogmatism displayed by the Methodist Church in Northern Australia in the early days, the fact that bigotry (in the form of intolerance of Yolyu religious practice) arrived relatively late, has created an environment in which continual adjustments can take place. It has resulted in a society in which religious pluralism is the norm, where Yolyu religious practice articulates with different Christian orientations. Eastern Arnhem Land remains a deeply religious society in which Yolyu and Christian religious forms are integrated within the same events, though often sequentially. Yet below the surface, both contemporary religious practices and interpretations of the missionary past are highly contested. The contested present reflects the contradictory history of YolyuEuropean engagement and the difficulties of the contemporary context of Yolyu lives.

\section{ACKNOWLEDGEMENTS}

I thank Frances Morphy and Pip Deveson for critical comments on this article and Margaret Smith of the Kluge-Ruhe archives at the University of Virginia for facilitating access to the correspondence between Edgar Wells and Ed Ruhe. 


\section{ENDNOTES}

${ }^{1}$ See for example Keith Cole, A History of the Church Missionary Society of Australia, Melbourne, Church Missionary Historical Publications, 1971; and Keith Cole, From Mission to Church: The CMS Mission to Aborigines of Arnhem Land 1908-1985, Bendigo, Keith Cole Publications, 1985.

2 Wilbur Chaseling, Yulengor: Nomads of Arnhem Land, Melbourne, Epworth Press, 1957.

3 Harold Thornell, A Bridge Over Time: Living in Arnhem Land, with Aborigines 1938-1944 as Told to Estelle Thomson, Melbourne, J. M. Dent, 1986.

4 Edgar Wells, Reward and Punishment in Arnhem Land 1962-1963, Canberra, Australian Institute of Aboriginal Studies, 1982.

5 ibid.

6 Howard and Frances Morphy, 'The myths of Ngalakan history', Man 19 (3), 1984, pp. 459-78.

7 Ted Egan, A Justice All Their Own: The Caledon Bay and Woodah Island Killings 1932-1933, Melbourne, Melbourne University Press, 1996.

8 Victor Charles Hall, Dreamtime Justice, Adelaide, Rigby, 1962.

9 Keith Cole, Groote Eylandt Pioneer, Melbourne, Church Missionary Historical Publications, 1971.

10 See Ronald Berndt, Arnhem Land: Its History and its People, Melbourne, Cheshire, 1954; and Andrew McMillan, An Intruder's Guide to East Arnhem Land, Sydney, Duffy \& Snellgrove, 2001.

11 Interview with Wilbur Chaseling in Sydney 11 December 1975, notes in possession of the author.

12 Grey himself was strongly supportive of Yolyu rights and subsequently played a significant role in facilitating the outstation movement in eastern Arnhem Land that was in part a response to the encroachment of mining operations.

13 Theodor Webb, Spears to Spades, Sydney, Department of Overseas Mission, 1938.

14 ibid.

15 Chaseling, op. cit.

16 Thornell, op. cit.

17 Ann Wells, Milingimbi: Ten Years in the Crocodile Islands of Arnhem Land, Sydney, Angus \& Robertson, 1963.

18 Mickey Dewar, The 'Black War' in Arnhem Land: Missionaries and the Yolngu 1908-1940, Darwin, Australian National University, North Australia Research Unit, 1992.

19 Chaseling interview.
20 Thornell, op. cit., p. 184.

21 ibid.

22 Chaseling, op. cit.

23 Fuata A. Taito, The Aborigines of the North / by a Rotuman, Sydney, Methodist Overseas Missions of Australasia, 1971.

24 Morphy interview with Chaseling. This discourse is described in slightly different form in Chaseling op. cit., p. 170-1.

25 Quoted and summarised from Chaseling op. cit., p. 170.

26 Wilbur Chaseling to Ed Ruhe, 12 November 1965. Correspondence in the Kluge-Ruhe Centre archives, University of Virginia.

27 Thornell op. cit., p. 171.

28 Ian Dunlop, (director), This is My Thinking, Sydney, Film Australia, 1995.

29 op. cit., p. 170.

30 Ian Dunlop, (director), We Believe in it-- We Know its True, Sydney, Film Australia, 1986.

31 For a detailed discussion of Yolyu religious iconography see Howard Morphy, Ancestral Connections: Art and an Aboriginal System of Knowledge, Chicago, University of Chicago Press, 1991. Chapter 5 discusses the concept of inside and outside knowledge (see also Ian Keen, Knowledge and Secrecy in an Aboriginal Religion, Oxford, Clarendon Press, 1994).

32 For detailed discussion see Ronald Berndt, An Adjustment Movement in Arnhem Land, Paris, Mouton, 1962; and Howard Morphy, 'Now you understand - an analysis of the way Yolnu have used sacred knowledge to maintain their autonomy', in Nicolas Peterson and Marcia Langton (eds), Aborigines, Land and Landrights, Canberra, Australian Institute of Aboriginal Studies, 1983, pp. 110-33.

33 In Maddock's apposite phrase it represented an attempt to remodel their society, see Ken Maddock, The Australian Aborigines: A Portrait of their Society, London, Allen Lane, The Penguin Press, 1972.

34 For a general account see Ann Wells, This their Dreaming: Legends of the Panels of Aboriginal Art in the Yirrkala Church, St Lucia, University of Queensland, 1971. For a discussion of the political context see Edgar Wells op. cit.

35 Edgar Wells to Ed Ruhe, May 3 1983. Correspondence in the Kluge-Ruhe Centre archives, University of Virginia.

36 For a more detailed analysis see Morphy, op. cit. 1983; and Howard Morphy, 'Art and politics: the bark petition and the Barunga statement' in Sylvia Kleinert and Margo Neale (eds), The Oxford Compan- 
ion to Aboriginal Art and Culture, Melbourne, Oxford University Press, 2000, pp. 100-102.

37 Chaseling op. cit., p. 171.

38 For some relevant discussion of contemporary Yolyu religious practice see Robert Bos, Jesus and the dreaming: Religion and social change in Arnhem Land, unpublished PhD thesis, University of Queensland, St Lucia, 1988; and Fiona Magowan 'Syncretism or synchronicity? Remapping the Yolngu feeling of place', The Australian Journal of Anthropology, Vol. 12, No. 3, 2001, pp. 275-90.

39 The Saltwater Paintings were produced in the late 1990 s in response to encroachments by non-Yolngu fishermen into the estuaries and intertidal zones of Yolngu clan lands. The collection is comprised of a set of paintings that map the relationships between people, ancestral beings and land along the eastern Arnhem Land coast. The paintings were acquired by the Australian National Maritime Museum and were published in Buku-Larrnggay Mulka (1999) Saltwater: Yirrkala Bark Paintings of Sea Country, Yirrkala and Sydney: Buku-Larrnggay Mulka in association with Jenny Isaacs Publishing. 